\title{
Raw Glycerol as an Alternative Carbon Source for Cultivation of Exopolysaccharide-Producing Bacteria
}

\author{
Renata Aguirre Trindade (Corresponding author) \\ School of Chemistry and Food, Federal University of Rio Grande \\ PO Box 474, Rio Grande, Brazil \\ Tel: 55-53-3232-6660Ｅ-mail: renaguirretrindade@gmail.com
}

\author{
Adriel Penha Munhoz \\ School of Chemistry and Food, Federal University of Rio Grande \\ PO Box 474, Rio Grande, Brazil \\ Tel: 55-53-3232-6660Ｅ-mail: adrielmunhoz@hotmail.com
}

\author{
Carlos André Veiga Burkert \\ School of Chemistry and Food, Federal University of Rio Grande \\ PO Box 474, Rio Grande, Brazil \\ Tel: 55-53-3232-6660Ｅ-mail: burkert@vetorial.net
}

Received: May 29, 2015 Accepted: July 17, 2015 Published: July 25, 2015

Doi: 10.5296/jab.v3n2.7695 URL: http://dx.doi.org/10.5296/ jab.v3n2.7695

\begin{abstract}
The large-scale use of biodiesel has shown significant environmental benefits as regards the reduction of global warming impacts. The increased generation of glycerol, the main byproduct of the reaction, makes necessary to propose alternatives to its use. In this context, the aim of this study was to evaluate raw glycerol (RG), a byproduct from biodiesel synthesis, as a carbon source for the cultivation of bacteria recognized as exopolysaccharides (EPSs) producers, compared with sucrose $(\mathrm{S})$ and with a mixture of both components in a ratio of 1:1 $\mathrm{w}$ : $\mathrm{W}$ (SRG). The bacteria used were: Xanthomonas campestris pv. mangiferaeindicae IBSBF
\end{abstract}




\section{Macrothink}

1230, Pseudomonas oleovorans NRRL B-14683, Sphingomonas capsulata NRRL B-4261 and Zymomonas mobilis NRRL B-4286. All bacteria were capable of growing and producing EPSs using RG as the sole carbon source. For X. campestris, EPSs concentration of around $4.00 \mathrm{~g} \mathrm{~L}^{-1}$ was found for the different carbon sources tested. For P. oleovorans, only the medium composed by $\mathrm{S}\left(0.85 \mathrm{~g} \mathrm{~L}^{-1}\right)$ differed from the other media, with better results being found using RG and SRG. S. capsulata showed higher concentration in the medium containing $\mathrm{S}$ and $\mathrm{SRG}$, around $3.40 \mathrm{~g} \mathrm{~L}^{-1}$, and in the medium containing $\mathrm{RG}$ this value decreased to $1.70 \mathrm{~g} \mathrm{~L}^{-1}$. Z. mobilis, on the other hand, showed a better result using SRG (1.41 $\mathrm{g} \mathrm{L}^{-1}$ ), and in the medium containing $\mathrm{S}$ and $\mathrm{RG}$, these values were lower, reaching 0.27 and $0.77 \mathrm{~g} \mathrm{~L}^{-1}$, respectively.

Keywords: Xanthomonas, Pseudomonas, Sphingomonas, Zymomonas, Crude glycerol, Reducing environmental impact 


\section{Introduction}

Petroleum is the main source of energy in the world. As a fossil fuel, a decrease in the oil reserves in the near future is expected. Then, the use of renewable fuels, such as biodiesel, has been encouraged, leading to increased production (Silva et al., 2009a). According to the Global Status Report (2014), Brazil has excelled in the production of biodiesel, reaching 2.9 billion liters in 2013, corresponding to the $3^{\text {rd }}$ position in the world rankings, behind the United States and Germany. The large-scale use of biodiesel has shown significant environmental benefits as regards the reduction of global warming impacts (European Biodiesel Board, 2014). Mainly obtained from vegetable oils, it contributes to the carbon cycle in the atmosphere, since the $\mathrm{CO}_{2}$ emitted during burning is reabsorbed by plants that will produce it, thus reducing emissions in the long run, causing less impact on global warming (Mota et al., 2009).

One consequence of this production is the growing generation of glycerol, the main byproduct of the transesterification of vegetable oils, which leads to the formation of methyl or ethyl esters (biodiesel). This increase is accompanied by a significant reduction in the prices of glycerol. According to Amaral et al. (2009), the biodiesel industry converted glycerol into a commodity of low commercial value, with the supply increasing well above the increase related to its traditional uses. The resulting raw glycerol from biodiesel synthesis usually has $55-90 \%$ purity. The rest consists of unconverted triacylglycerols, unconverted methanol or ethanol, biodiesel, soaps and others (Amaral et al., 2009).

On the other hand, a high potential for application in various industrial segments has arisen for microbial biopolymers excreted by the cells, also called exopolysaccharides (EPSs). They are being used in food, pharmaceutical and chemical products, among others (Luvielmo \& Scamparini, 2009; Freitas et al., 2011; Prasanna et al., 2012).

The most used carbon sources for the production of EPSs have been carbohydrates like glucose (Bajaj et al., 2006; Zhang et al., 2015) and sucrose (Rottava et al., 2009; Reis et al., 2010; Zhu et al., 2013; Silbir et al., 2014; Zhang et al., 2015). However, the high cost of these sources of carbon has a direct impact on production costs, limiting the market potential of these biopolymers. To reduce costs, byproducts and industrial wastes have been used. Berwanger et al. (2006) and Banik et al. (2007) used molasses as a carbon source for the cultivation of Sphingomonas capsulata and Sphingomonas paucimobilis, respectively, in order to produce EPSs. Mesomo et al. (2009) and Silva et al. (2009b) investigated whey as a carbon source for the production of xanthan gum from Xanthomonas campestris. Freitas et al. (2010) produced a biopolymer by Pseudomonas oleovorans and Reis et al. (2010) produced xanthan gum by $X$. campestris using raw glycerol as carbon source, however there are still few studies with this carbon source for the production of EPSs.

In our research group, raw glycerol has been proposed as a carbon source for microbial cultivation. Santos et al. (2013) investigated the possibility of using raw glycerol as a substrate for yeast biomass production as a source of proteins. Machado Junior et al. (2015) evaluated the effects of aeration and agitation on growth parameters and lipid content in the cultivation of Yarrowia lipolytica using raw glycerol as carbon source. In the work of Spier et 
al. (2015), 12 different yeast strains were evaluated to gauge their ability to accumulate lipids using raw glycerol as the main carbon source

In this context, this paper proposes to evaluate the raw glycerol as a carbon source, in total or partial replacement of sucrose commonly used in cultivation of different bacteria known to produce EPSs of commercial importance.

\section{Materials and Methods}

\subsection{Materials}

\subsubsection{Microorganisms}

X. campestris pv. mangiferaeindicae IBSBF 1230 was obtained from the Culture Collection of Phytobacteria of the Biological Institute (IBSBF), Campinas, Brazil. P. oleovorans NRRL B-14683, S. capsulata NRRL B-4261 and Zymomonas mobilis subspecies mobilis NRRL B-4286 were obtained from the ARS Culture Collection (National Center for Agricultural Utilization Research, Peoria, United States). The microorganisms were supplied lyophilized.

\subsubsection{Raw Glycerol}

Raw glycerol was supplied by BS Bios Indústria e Comércio de Biodiesel Sul Brasil S/A (Passo Fundo, Brazil), with the following composition $(\% \mathrm{w} / \mathrm{w}): 81.92$ glycerol, 11.29 moisture, 5.38 ash, 1.41 non-glyceridic organic matter, $\mathrm{pH} 5.39$.

\subsection{Cultivation Assays}

\subsubsection{Preparation of Inoculum}

From the lyophilized and previously rehydrated cultures, successive transfers were performed in order to reactivate the microbial cultures. For $X$. campestris pv. mangiferaeindicae IBSBF 1230, it was used YM (Yeast Malt) agar, with the following composition $\left(\mathrm{g} \mathrm{L}^{-1}\right): 3$ yeast extract; 3 malt extract; 5 peptone; 20 glucose; 10 agar; and pH 7.2 (Mesomo et al., 2009). For P. oleovorans NRRL B-14683 and S. capsulata NRRL B-4261, the medium used contained (g $\mathrm{L}^{-1}$ ): 20 glucose; 5 peptone; 3 yeast extract; 5 sodium chloride; 20 agar; and $\mathrm{pH}$ 6.8-7.0 (Bajaj et al., 2006). As for Z. mobilis NRRL B-4286, the medium used contained ( $\left.\mathrm{g} \mathrm{L}^{-1}\right)$ : 20 sucrose; 2.5 yeast extract; $1 \mathrm{KH}_{2} \mathrm{PO}_{4} ; 1\left(\mathrm{NH}_{4}\right)_{2} \mathrm{SO}_{4} ; 0.5 \mathrm{MgSO}_{4} .7 \mathrm{H}_{2} \mathrm{O} ; 20$ agar (Oliveira et al., 2007).

Bacterial cultures were scraped from each slant tube with the aid of $10 \mathrm{~mL}$ of $0.1 \%$ peptone diluent, and the suspension was inoculated into $500 \mathrm{~mL}$ Erlenmeyer flasks with cotton plugs that contained $90 \mathrm{~mL}$ of the medium, and incubated in a rotary shaker (Tecnal TE-424, Brazil) at $28^{\circ} \mathrm{C}$ and $150 \mathrm{rpm}$ until the optical density at $560 \mathrm{~nm}$ reached $1.9-2.1$, corresponding to the logarithmic phase of microbial growth (Moreira et al., 2001; Mesomo et al., 2009).

\subsubsection{Shaken Flasks Cultivation}

The inoculum for each bacterial strain, representing $10 \%$ of the total volume $(10 \mathrm{~mL})$ was transferred to $500 \mathrm{~mL}$ Erlenmeyer flasks containing $90 \mathrm{~mL}$ of the culture medium. The flasks were kept in a rotary shaker (Tecnal TE-424, Brazil) at $28{ }^{\circ} \mathrm{C}$ and $200 \mathrm{rpm}$ (Moreira et al., 2001). 
Different culture media were used for each microorganism (Table 1). As carbon sources, sucrose (S), raw glycerol (RG) and a mixture of both (SRG), 1:1 w:w, were used, as suggested by Reis et al. (2010), since sucrose is the usual source of carbon for the production of the studied EPSs. The amount of raw glycerol used in the media considered its composition in order to result the concentration of substrate indicated in Table 1.

Table 1. Media composition for the different EPS-producing bacteria

\begin{tabular}{|c|c|c|}
\hline Microorganism & Medium composition $\left(\mathrm{g} \mathrm{L}^{-1}\right)$ & Reference \\
\hline X. campestris & $\begin{array}{l}50 \text { carbon source; } 2.5\left(\mathrm{NH}_{4}\right) \mathrm{H}_{2} \mathrm{PO}_{4} ; 5.0 \quad \mathrm{~K}_{2} \mathrm{HPO}_{4} \text {; } \\
0.006 \mathrm{H}_{3} \mathrm{BO}_{3} ; 2 \quad\left(\mathrm{NH}_{4}\right)_{2} \mathrm{SO}_{4} ; 0.0024 \mathrm{FeCl}_{3} ; 0.002 \\
\mathrm{CaCl}_{2} .2 \mathrm{H}_{2} \mathrm{O} ; 0.002 \mathrm{ZnSO}_{4} ; \mathrm{pH} 7.0\end{array}$ & $\begin{array}{l}\text { Reis et al. } \\
(2010)\end{array}$ \\
\hline P. ol & $\begin{array}{l}25 \text { carbon source; } 3.3\left(\mathrm{NH}_{4}\right)_{2} \mathrm{HPO}_{4} ; 5.8 \mathrm{~K}_{2} \mathrm{HPO}_{4} ; 3.7 \\
\mathrm{KH}_{2} \mathrm{PO}_{4} ; 10 \mathrm{~mL} \text { solution } \mathrm{MgSO}_{4} 100 \mathrm{mM} ; 1 \mathrm{~mL} \\
\text { solution of micronutrients*; } \mathrm{pH} 7.0\end{array}$ & $\begin{array}{l}\text { Freitas et al. } \\
(2010)\end{array}$ \\
\hline S. capsulata & $\begin{array}{l}20 \text { carbon source; } 10 \mathrm{Na}_{2} \mathrm{HPO}_{4} ; 1 \mathrm{~K}_{2} \mathrm{SO}_{4} ; 1 \mathrm{NaCl} \text {; } \\
0.15\left(\mathrm{NH}_{4}\right)_{2} \mathrm{SO}_{4} ; 0.2 \mathrm{MgSO}_{4} .7 \mathrm{H}_{2} \mathrm{O} ; 0.01 \mathrm{CaCl}_{2} .2 \mathrm{H}_{2} \mathrm{O} \text {; } \\
0.001 \mathrm{FeSO}_{4} .7 \mathrm{H}_{2} \mathrm{O} ; 0.5 \text { yeast extract; } \mathrm{pH} 6.8-7.0\end{array}$ & $\begin{array}{l}\text { Bajaj et al. } \\
(2006)\end{array}$ \\
\hline Z. mobilis & $\begin{array}{l}20 \text { carbon source; } 2.5 \text { yeast extract; } 1 \mathrm{KH}_{2} \mathrm{PO}_{4} ; 1 \\
\left(\mathrm{NH}_{4}\right)_{2} \mathrm{SO}_{4} ; 0.5 \mathrm{MgSO}_{4} .7 \mathrm{H}_{2} \mathrm{O} ; \mathrm{pH} 7.0\end{array}$ & $\begin{array}{l}\text { Oliveira et al. } \\
(2007)\end{array}$ \\
\hline
\end{tabular}

*Solution of micronutrients (in $\mathrm{g} \mathrm{L}^{-1} \mathrm{HCl} 1 \mathrm{~N}$ ): $2.78 \mathrm{FeSO}_{4} .7 \mathrm{H}_{2} \mathrm{O} ; 1.98 \mathrm{MnCl}_{2} .4 \mathrm{H}_{2} \mathrm{O} ; 2.81$ $\mathrm{CoSO}_{4} .7 \mathrm{H}_{2} \mathrm{O} ; 1.67 \mathrm{CaCl}_{2} .2 \mathrm{H}_{2} \mathrm{O} ; 0.17 \mathrm{CuCl}_{2} .2 \mathrm{H}_{2} \mathrm{O} ; 0.29 \mathrm{ZnSO}_{4} .7 \mathrm{H}_{2} \mathrm{O}$.

\subsection{Analytical Methods}

Aliquots $(10 \mathrm{~mL})$ were taken at 0,24 and $48 \mathrm{~h}$, based on previous assays (data not shown), in order to determine biomass concentration. Samples were centrifuged for $12 \mathrm{~min}$ (Cientec CT-5000R, Brazil) and the pellet was recovered after washing with peptone diluent. The biomass concentration was estimated by measuring the absorbance at $560 \mathrm{~nm}$ in a spectrophotometer (Biospectro SP-22, China). A calibration curve between $\mathrm{OD}_{560}$ and the cell dry-weight concentration $\left(\mathrm{g} \mathrm{L}^{-1}\right)$ was first established for each microorganism (Prieto et al., 2008).

The recovery of EPSs from the medium in $48 \mathrm{~h}$ cultivation was performed by centrifugation (Cientec CT-5000R, Brazil) of all content of the flasks at $3,400 \times g$ for 30 min at $4{ }^{\circ} \mathrm{C}$, followed by precipitation of EPS by the addition of ethanol $96.4^{\circ} \mathrm{GL}(1: 4 \mathrm{v}: \mathrm{v})$, standing for $24 \mathrm{~h}$ at $4{ }^{\circ} \mathrm{C}$ and centrifuged again for 30 min under refrigeration $\left(4^{\circ} \mathrm{C}\right)$ (Mesomo et al., 2009).

The EPS concentration was determined gravimetrically by drying of precipitates at $50{ }^{\circ} \mathrm{C}$ 
(Quimis, Q314M242, Brazil) until constant weight (Sartorius, TE214S, Brazil), relating to the sample volume (Mesomo et al., 2009). The EPSs values shown correspond to the extracellular material precipitable by ethanol, as described by Staudt et al. (2012), since there was no further purification of the precipitate. The productivity was obtained by concentration of the EPS divided by the respective cultivation time (Rottava et al., 2009).

\subsection{Statistical Analysis}

All cultivations were performed in triplicate. The results were analyzed by analysis of variance and Tukey's test (Montgomery, 2004) in order to verify the existence of significant differences between the carbon sources for the same micro-organism, at $95 \%$ confidence level $(\mathrm{p}<0.05)$.

\section{Results and Discussion}

\subsection{Biomass}

Figure 1 shows the monitoring of biomass in the cultivation of $X$. campestris pv. mangiferaeindicae IBSBF 1230, P. oleovorans NRRL B-14683, S. capsulata NRRL B-4261 and Z. mobilis NRRL B-4286, respectively, for the different carbon sources.

For almost all bacteria in the study, the highest biomass concentration was observed in $48 \mathrm{~h}$ cultivation. The highest biomass concentration for $X$. campestris was found using SRG $(0.14$ $\mathrm{g} \mathrm{L}^{-1}$ ), differing significantly $(\mathrm{p}<0.05)$ from the other carbon sources (around $0.12 \mathrm{~g} \mathrm{~L}^{-1}$ ). For $P$. oleovorans, the highest biomass concentration was obtained with the medium containing only RG $\left(5.29 \mathrm{~g} \mathrm{~L}^{-1}\right)$ as a carbon source, differing significantly $(\mathrm{p}<0.05)$ from other media. The concentration of biomass for $S$. capsulata in the three carbon sources did not differ significantly $(\mathrm{p}>0.05)$, reaching around $0.95 \mathrm{~g} \mathrm{~L}^{-1}$. In the cultivation of Z. mobilis, the highest concentration of biomass was reached with the medium $\mathrm{S}\left(0.77 \mathrm{~g} \mathrm{~L}^{-1}\right)$, differing significantly $(\mathrm{p}<0.05)$ from the other media, with a sharp drop in the concentration of biomass $\left(0.21 \mathrm{~g} \mathrm{~L}^{-1}\right)$ when $\mathrm{RG}$ was used as carbon source.

Mesomo et al. (2009), in the cultivation of X. campestris mangiferaeindicae IBSBF 1230 using cheese whey as carbon source, found a biomass concentration varying from 0.6 to $5 \mathrm{~g}$ $\mathrm{L}^{-1}$, according to aeration and agitation conditions in a $2.5 \mathrm{~L}$ bench-scale bioreactor.

Freitas et al. (2010), using P. oleovorans, observed that using raw glycerol as carbon source, the highest biomass concentration was $9.55 \mathrm{~g} \mathrm{~L}^{-1}$ in $48 \mathrm{~h}$ when temperature was $30^{\circ} \mathrm{C}$. When using a temperature of $25^{\circ} \mathrm{C}$, a concentration around $3.00 \mathrm{~g} \mathrm{~L}^{-1}$ was reached. This result is in accordance with the present study $\left(5.29 \mathrm{~g} \mathrm{~L}^{-1}\right)$, conducted at a temperature of $28^{\circ} \mathrm{C}$.

West and Strohfus (1998) found for S. paucimobilis a biomass concentration of $0.82 \mathrm{~g} \mathrm{~L}^{-1}$ in $48 \mathrm{~h}$ when cultivated with sucrose as carbon source, a result similar to those found in this study for $S$. capsulata $\left(0.96 \mathrm{~g} \mathrm{~L}^{-1}\right)$.

Oliveira et al. (2007), using $250 \mathrm{~g} \mathrm{~L}^{-1}$ sucrose (carbon source) in $24 \mathrm{~h}$ of cultivation, found a biomass concentration of $0.85 \mathrm{~g} \mathrm{~L}^{-1}$, a result similar to that found in this study for Z. mobilis $\left(0.77 \mathrm{~g} \mathrm{~L}^{-1}\right)$ where lower concentrations of sucrose were used. 


\section{Macrothink}

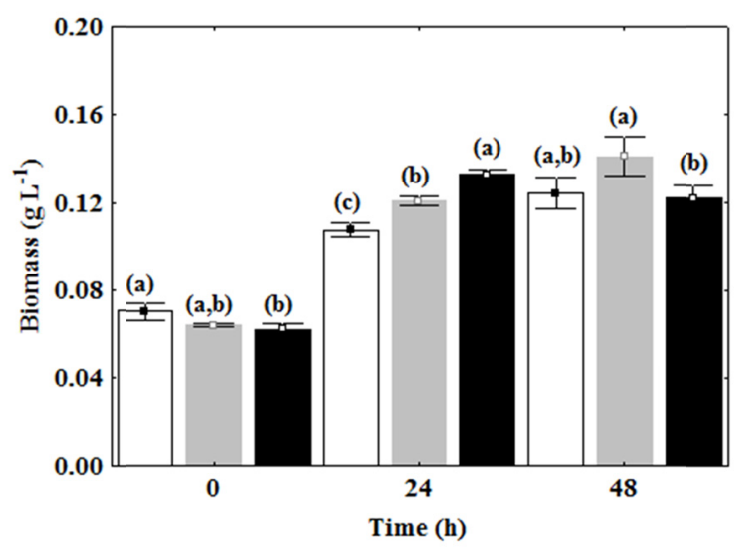

(a)

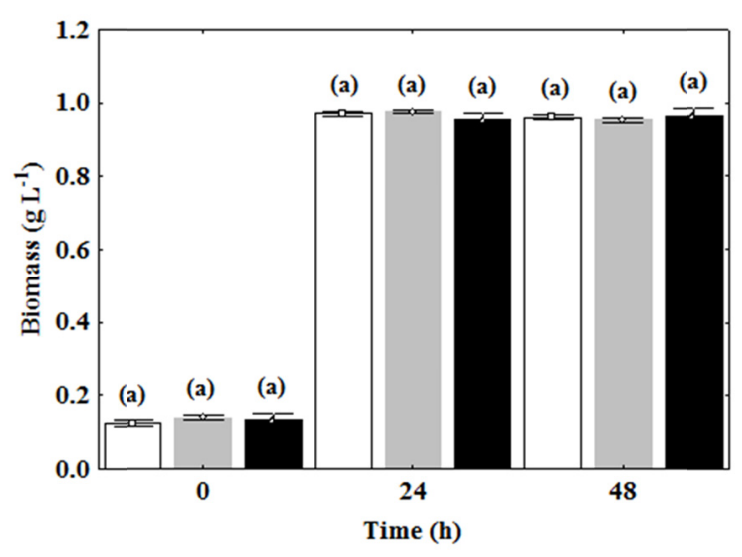

(c)

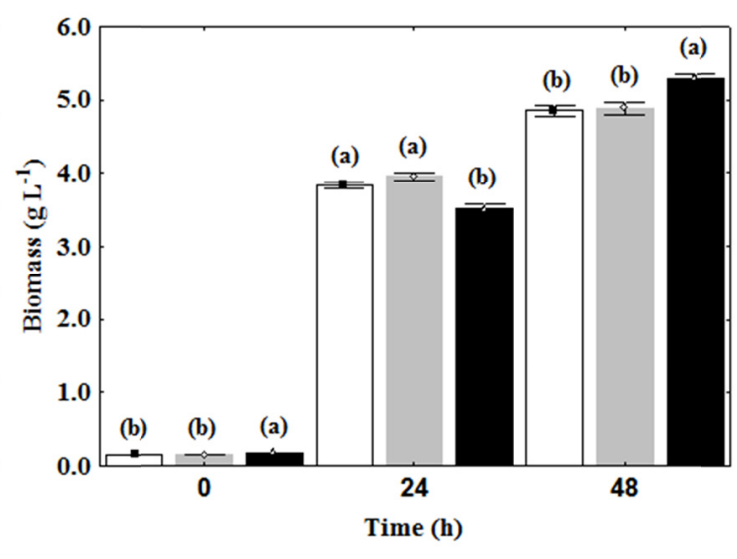

(b)

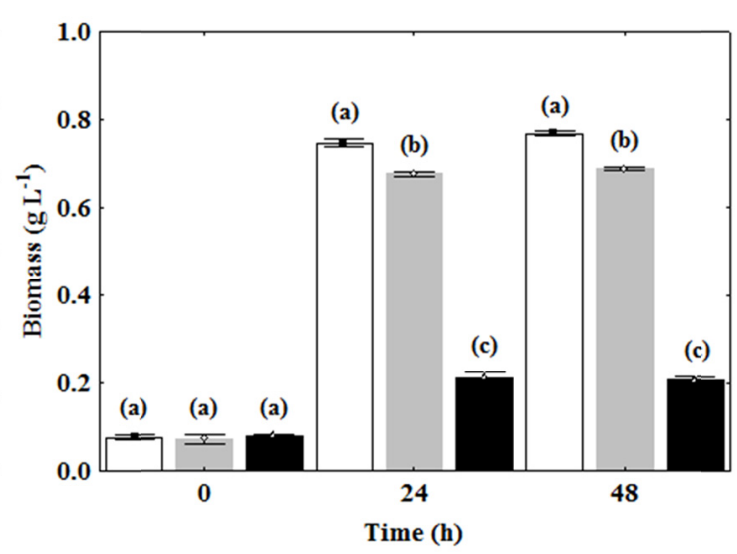

(d)

Figure 1. Biomass for X. campestris IBSBF 1230 (a), P. oleovorans NRRL B-14683 (b), $S$. capsulata NRRL B-4261 (c) and Z. mobilis NRRL B-4286 (d) cultivated in a medium containing S ( $\square)$, SRG ( $\square$ ) and RG ( $\square$ ). Different lowercase letters indicate a significant difference between the media for the same bacteria at the same cultivation time $(p<0.05)$

\subsection{EPSs Concentration and Productivity}

The EPSs concentration was evaluated at $48 \mathrm{~h}$ of cultivation (Table 2). The study was conducted in shaken flasks. In this case, the volume of sample collected $(10 \mathrm{~mL})$ did not permit the quantification of EPSs along time, because it is necessary a minimum weight for gravimetric determination. So, the EPSs concentration was determined at the end of cultivation (48 h), when it was possible to recovery all supernatant.

For $X$. campestris, $4.98 \mathrm{~g} \mathrm{~L}^{-1}$ of EPSs were found when RG was used as carbon source, not differing significantly from the EPSs produced with $\mathrm{S}\left(4.55 \mathrm{~g} \mathrm{~L}^{-1}\right)$. The medium containing only $\mathrm{S}$ was also not significantly different from medium containing SRG $\left(4.07 \mathrm{~g} \mathrm{~L}^{-1}\right)$.

$X$. campestris is a gram-negative bacterium recognized as a xanthan gum producer, the 
biopolymer most widely accepted commercially. It can be used in foods and other segments as a thickening, stabilizing and emulsifying agent (Rottava et al., 2009). Reis et al. (2010) evaluated the ability of Xanthomonas sp C1 and C9 to produce a biopollymer in a medium containing the same carbon sources used in this study (S, SRG and RG). The authors found that the use of sucrose and a mixture of sucrose and residual glyceroll did not represent significant differences, producing xanthan gum at a concentration of around $0.33 \mathrm{~g} \mathrm{~L}^{-1}$ for S. As for the medium consisting only of RG, the concentration of this biopolymer was 0.157 and $0.186 \mathrm{~g} \mathrm{~L}^{-1}$ for $\mathrm{C} 1$ and $\mathrm{C} 9$, respectively, different from the other carbon sources. Moreira et al. (2001) evaluated the production of xanthan gum by 18 strains of $X$. campestris pv pruni, using sucrose as a carbon source, at $28{ }^{\circ} \mathrm{C}$ and $200 \mathrm{rpm}$ agitation, yielding gum concentrations ranging from 2.3 to $8.3 \mathrm{~g} \mathrm{~L}^{-1}$ after $72 \mathrm{~h}$ of cultivation.

Table 2. Mean values* of EPSs concentration (standard deviation) for different bacteria at 48 $\mathrm{h}$ of cultivation (values are expressed in $\mathrm{g} \mathrm{L}^{-1}$ )

\begin{tabular}{llllll}
\hline $\begin{array}{l}\text { Carbon } \\
\text { Source }\end{array}$ & $\begin{array}{l}X . \quad \text { campestris } \\
\text { IBSBF 1230 }\end{array}$ & $\begin{array}{l}P . \text { oleovorans } \\
\text { NRRL B-14683 }\end{array}$ & $\begin{array}{l}S . \quad \text { capsulata } \\
\text { NRRL B-4261 }\end{array}$ & $\begin{array}{l}\text { Z. mobilis } \\
\text { NRRL B-4286 }\end{array}$ \\
\hline $\mathrm{S}$ & $4.55(0.37)^{\mathrm{a}, \mathrm{b}}$ & $0.84(0.05)^{\mathrm{b}}$ & $3.44(0.22)^{\mathrm{a}}$ & $0.27(0.03)^{\mathrm{c}}$ \\
$\mathrm{SRG}$ & $4.07(0.14)^{\mathrm{b}}$ & $4.11(0.13)^{\mathrm{a}}$ & $3.51(0.14)^{\mathrm{a}}$ & $1.42(0.16)^{\mathrm{a}}$ \\
$\mathrm{RG}$ & $4.98(0.36)^{\mathrm{a}}$ & $3.99(0.20)^{\mathrm{a}}$ & $1.87(0.19)^{\mathrm{b}}$ & $0.77(0.09)^{\mathrm{b}}$ \\
\hline
\end{tabular}

*Different lowercase letters indicate a significant difference between the media for the same bacteria $(\mathrm{p}<0.05)$.

Table 3. Mean values* of EPSs productivity (standard deviation) for different bacteria at $48 \mathrm{~h}$ of cultivation (values are expressed in $\mathrm{g} \mathrm{L}^{-1} \mathrm{~h}^{-1}$ )

\begin{tabular}{llllll}
\hline $\begin{array}{l}\text { Carbon } \\
\text { Source }\end{array}$ & $\begin{array}{l}X . \quad \text { campestris } \\
\text { IBSBF 1230 }\end{array}$ & $\begin{array}{l}P . \quad \text { oleovorans } \\
\text { NRRL B-14683 }\end{array}$ & $\begin{array}{l}S . \quad \text { capsulata } \\
\text { NRRL B-4261 }\end{array}$ & $\begin{array}{l}\text { Z. mobilis } \\
\text { NRRL B-4286 }\end{array}$ \\
\hline $\mathrm{S}$ & $0.09(0.01)^{\mathrm{a}}$ & $0.02(<0.01)^{\mathrm{b}}$ & $0.07(<0.01)^{\mathrm{a}}$ & $0.01(<0.01)^{\mathrm{c}}$ \\
$\mathrm{SRG}$ & $0.08(<0.01)^{\mathrm{b}}$ & $0.09(<0.01)^{\mathrm{a}}$ & $0.07(<0.01)^{\mathrm{a}}$ & $0.03(<0.01)^{\mathrm{a}}$ \\
$\mathrm{RG}$ & $0.10(0.01)^{\mathrm{a}}$ & $0.08(<0.01)^{\mathrm{a}}$ & $0.04(<0.01)^{\mathrm{b}}$ & $0.02(<0.01)^{\mathrm{b}}$ \\
\hline
\end{tabular}

*Different lowercase letters indicate a significant difference between the media for the same bacteria $(\mathrm{p}<0.05)$. 
For P. oleovorans, it can be seen that a higher concentration of EPSs was found with SRG (4.11 $\mathrm{g} \mathrm{L}^{-1}$ ) and $\mathrm{RG}$ (3.99 $\mathrm{g} \mathrm{L}^{-1}$ ), not differing significantly from each other. The concentration of EPSs in the sucrose medium was rather low $\left(0.84 \mathrm{~g} \mathrm{~L}^{-1}\right)$, differing significantly from the others.

P. oleovorans is mentioned as an EPS producer, but not available commercially. It is characterized by the presence of neutral sugars (such as galactose, glucose, mannose and rhamnose) and acyl groups substituents (pyruvil, acetyl and succinyl) (Freitas et al., 2010).

Hilliou et al. (2009), in the cultivation of P. oleovorans NRRL B-14682 using $25 \mathrm{~g} \mathrm{~L}^{-1}$ of glycerol as carbon source and $3.3 \mathrm{gL}^{-1}\left(\mathrm{NH}_{4}\right)_{2} \mathrm{HPO}_{4}$ as nitrogen source, at $\mathrm{pH}$ 6.75-6.85 and $0.125 \mathrm{vvm}$ aeration, obtained $13.3 \mathrm{~g} \mathrm{~L}^{-1}$ of EPSs after 7 days of cultivation, however they used a $10 \mathrm{~L}$ bench-scale bioreactor, where the conditions of agitation and aeration are much more efficient.

When $S$. capsulata is evaluated, it can be seen that the highest concentration of EPSs was found when using $\mathrm{S}\left(3.44 \mathrm{~g} \mathrm{~L}^{-1}\right)$ and SRG $\left(3.51 \mathrm{~g} \mathrm{~L}^{-1}\right)$ as a carbon source, not differing from each other, with the concentration found being rather low $\left(1.87 \mathrm{~g} \mathrm{~L}^{-1}\right)$ when $\mathrm{RG}$ was used as carbon source.

A number of bacteria of the genus Sphingomonas produce polysaccharides called sphingans. The sphingans gellan, wellan, rhamsan and diutan are produced commercially for use in food, oilfield or personal care applications, presenting rheological properties similar to xanthan gum. They are composed by a generally conserved tetrasaccharide backbone structure and different side chains (Coleman et al., 2008).

For Z. mobilis, it can be seen that there was a higher concentration of EPSs in the medium containing a mixture of SRG $\left(1.42 \mathrm{~g} \mathrm{~L}^{-1}\right)$, followed by RG $\left(0.77 \mathrm{~g} \mathrm{~L}^{-1}\right)$ and $\mathrm{S}\left(0.27 \mathrm{~g} \mathrm{~L}^{-1}\right)$.

The levan is an EPS formed by fructose units that have a wide variety of applications. The levan is used in foods as color and flavor vehicle and as a source of fructose and fructooligosaccharides. It can be used in medicine as a hypo-cholesterol, antitumor, immune modulator, anti-inflammatory and plasma substitute agent (Ernandes \& Cruz, 2011; Oliveira et al., 2007).

By comparing Figure 1 and Table 2, it can be seen that there is no relation between biomass and EPSs production in $48 \mathrm{~h}$ cultivation. A similar behavior was also observed by Kawai et al. (2006) for microalgae and by Maziero et al. (1999) for basidiomycetes.

Productivity is receiving a lot of attention, because it is fundamental to the success of a microbial process. As for productivity in EPSs, according to Table 3, it can be seen that for $X$. campestris the highest yield was in the medium with $\mathrm{S}\left(0.09 \mathrm{~g} \mathrm{~L}^{-1} \mathrm{~h}^{-1}\right)$ and $\mathrm{RG}\left(0.10 \mathrm{~g} \mathrm{~L}^{-1} \mathrm{~h}^{-1}\right)$, not differing significantly $(\mathrm{p}>0.05)$ from each other. For $P$. oleovorans, a greater yield was found when SRG $\left(0.09 \mathrm{~g} \mathrm{~L}^{-1} \mathrm{~h}^{-1}\right)$ and RG $\left(0.08 \mathrm{~g} \mathrm{~L}^{-1} \mathrm{~h}^{-1}\right)$ were used as carbon sources, not differing significantly $(\mathrm{p}>0.05)$ from each other. With $S$. capsulata, a greater yield was found when SRG $\left(0.07 \mathrm{~g} \mathrm{~L}^{-1} \mathrm{~h}^{-1}\right)$ and $\mathrm{S}\left(0.07 \mathrm{~g} \mathrm{~L}^{-1} \mathrm{~h}^{-1}\right)$ were used as carbon sources, not differing significantly $(\mathrm{p}>0.05)$ from each other. For Z. mobilis, the highest yield was 
obtained when SRG mixture $\left(0.03 \mathrm{~g} \mathrm{~L}^{-1} \mathrm{~h}^{-1}\right)$ was used as a carbon source, differing significantly $(\mathrm{p}<0.05)$ from the other carbon sources.

Berwanger et al. (2006) evaluated the ability of Sphingomonas capsulata ATCC 14666 to produce a biopolymer, using raw and pretreated molasses and textured soybean protein (TSP) waste as carbon source by testing different concentrations $\left(2.66,4\right.$ and $6.08 \%$ ), at $28 \pm 2{ }^{\circ} \mathrm{C}$, $208 \mathrm{rpm}$ and $72 \mathrm{~h}$. The best productivity was found for pretreated molasses $8 \%\left(0.290 \mathrm{~g} \mathrm{~L}^{-1}\right.$ $\left.\mathrm{h}^{-1}\right)$, followed by the aqueous extract of the TSP residue $6 \%\left(0.240 \mathrm{~g} \mathrm{~L}^{-1} \mathrm{~h}^{-1}\right)$ and crude molasses $8 \%\left(0.190 \mathrm{~g} \mathrm{~L}^{-1} \mathrm{~h}^{-1}\right)$. Freitas et al. (2010) evaluated the productivity of the bacterium $P$. oleovorans using RG as carbon source and found a yield of $0.0341 \mathrm{~g} \mathrm{~L}^{-1} \mathrm{~h}^{-1}$ at $25{ }^{\circ} \mathrm{C}$ and $0.083 \mathrm{~g} \mathrm{~L}^{-1} \mathrm{~h}^{-1}$ at $30^{\circ} \mathrm{C}$, the latter being the same value found in this work, at a temperature of $28^{\circ} \mathrm{C}$.

Based on the results presented in this work, it was possible to use a low-cost substrate with high availability for different EPSs production, with potential to add value to the biodiesel production chain and reduce the environmental impacts of this industrial process.

\section{Conclusions}

By comparing $X$. campestris pv. mangiferaeindicae IBSBF 1230, P. oleovorans NRRL B-14683, S. capsulata NRRL B-4261 and Z. mobilis NRRL B-4286, all strains were able to grow and produce EPSs in medium containing only RG as a carbon source in $48 \mathrm{~h}$ cultivation, with the bacteria $X$. campestris and $P$. oleovorans being able to produce the same or higher concentrations of EPSs when only RG was used as a carbon source compared to the other carbon sources, not having a defined relationship between the concentration of biomass and production of EPSs. Thus, it was shown that RG is a potential alternative carbon source for substituting sucrose in the cultivation of some EPSs-producing bacteria.

\section{Acknowledgements}

The authors would like to thank the State Research Foundation of Rio Grande do Sul (FAPERGS), the Brazilian Council for Scientific and Technological Development (CNPq), the Brazilian Federal Agency for the Support and Evaluation of Graduate Education (CAPES), and the Institutional Program for Students Development of Federal University of Rio Grande (PDE/FURG) for their financial support.

\section{References}

Amaral, P. F. F., Ferreira, T. F., Fontes, G. C., \& Coelho, M. A. Z. (2009). Glycerol valorization: New biotechnological routes. Food and bioproducts processing, 87, 179-186. http://dx.doi.org/10.1016/j.fbp.2009.03.008

Bajaj, I. B., Saudagar, P. S., Singhal, R. S., \& Pandey, A. (2006). Statistical approach to optimization of fermentative production of gellan gum from Sphingomonas paucimobilis ATCC 31461. Journal of bioscience and bioengineering, 102, 150-156. http://dx.doi.org/10.1263/jbb.102.150

Banik, R. M., Santhiagu, A., \& Upadhyay, S. N. (2007). Optimization of nutrients for gellan 
gum production by Sphingomonas paucimobilis ATCC-31461 in molasises based medium using response surface methodology. Bioresource technology, 98, 792-797. http://dx.doi.org/10.1016/j.biortech.2006.03.012

Berwanger, A. L. S., Domingues, N. M., Vanzo, L. T., Di Luccio, M., Treichel, H., Padilha, F. F., \& Scamparini, A. R. P. (2006). Production and rheological characterization of biopolymer of Sphingomonas capsulata ATCC 14666 using conventional and industrial media. Applied $\begin{array}{llll}\text { biochemistry and } \quad \text { biotechnology, } & \text { 942-950. }\end{array}$ http://dx.doi.org/10.1007/978-1-59745-268-7_79

Coleman, R. J., Patel, Y. N., \& Harding, N. E. (2008). Identification and organization of genes for diutan polysaccharide synthesis from Sphingomonas sp. ATCC. 53159. Journal of industrial microbiology \& biotechnology, 35, 263-274. http://dx.doi.org/10.1007/s10295-008-0303-3

Ernandes, F. M. P. G., \& Cruz, C. H. G. (2011). Uso de caldo de cana-de-açúcar para produção de levana por Zymomonas mobilis CCT4494. Ciência e agrotecnologia, 35, 354-360. http://dx.doi.org/10.1590/S1413-70542011000200017

European Biodiesel Board - EBB. (2014). Retrieved November 04, 2014, from http://www.ebb-eu.org/biodiesel.php

Freitas, F., Alves, V. D., Pais, J., Carvalheira, M., Costa, N., Oliveira, R., \& Reis, M. A. M. (2010). Production of a new exopolysaccharide (EPS) by Pseudomonas oleovorans NRRL B-14682 grown on glycerol. Process biochemistry, 45, 297-305. http://dx.doi.org/10.1016/j.procbio.2009.09.020

Freitas, F., Alves, V. D., \& Reis, M. A. M. (2011). Advances in bacterial exopolysaccharides: From production to biotechnological applications. Trends in biotechnology, 29, 388-398. http://dx.doi.org/10.1016/j.tibtech.2011.03.008

Kawai, L. A., Pinotti, M. H. P., \& Celigoi, M. A. P. C. (2006). Produção de exopolissacarídeos pela cianobactéria Nostoc $s p$ em diferentes concentrações de nitrogênio e glicose. Semina: Ciências biológicas e da saúde, 27, 33-39. http://dx.doi.org/10.5433/1679-0367.2006v27n1p33

Global Status Report. (2014). Renewables 2014. Retrieved July 10, 2015, from http://www.ren21.net/Portals/0/documents/Resources/GSR/2014/GSR2014_full\%20report_lo w\%20res.pdf

Hilliou, L., Freitas, F., Oliveira, R., Reis, M. A. M., Lespineux, D., Grandfils, C., \& Alves, V. D. (2009). Solution properties of an exopolysaccharide from a Pseudomonas strain obtained using glycerol as sole carbon source. Carbohydrate polymers, 78, 526-532. http://dx.doi.org/10.1016/j.carbpol.2009.05.011

Luvielmo, M. M., \& Scamparini, A. R. P. (2009). Goma xantana: Produção, recuperação, propriedades e aplicação. Estudos tecnológicos, 5, 50-67. http://dx.doi.org/10.4013/ete.2009.51.04 
Machado-Junior, F. R. S., Michelon, M., Dalcanton, F., Furlong, E. B., Burkert, J. F. M., \& Burkert, C. A. V. (2015). Biomass production by Yarrowia lipolytica as a source of lipids: Bench scale cultivation on raw glycerol-based medium. International food research journal, 22, 1253-1260.

Maziero, R., Cavazzoni, V., \& Bononi, V. L. R. (1999). Screening Basidiomycetes for the production of exopolysaccharide and biomass in submerged culture. Revista de microbiologia, 30, 77-84. http://dx.doi.org/10.1590/S0001-37141999000100015

Mesomo, M., Silva, M. F., Boni, G., Padilha, F. F., Mazutti, M., Mossi, A., ... Treichel, H. (2009). Xanthan gum produced by Xanthomonas campestris from cheese whey: Production optimisation and rheological characterisation. Journal of the science of food and agriculture, 89, 2440-2445. http://dx.doi.org/10.1002/jsfa.3743

Montgomery, D. C. (2004). Introdução ao controle estatístico de qualidade (4 ${ }^{\text {th }}$ ed.). Rio de Janeiro, Brasil: Editora LTC.

Moreira, A. S., Vendruscolo, J. L. S., Gil-Turnes, C., \& Vendruscolo, C. T. (2001). Screening among 18 novel strains of Xanthomonas campestris pv pruni. Food hydrocolloids, 15, 469-474. http://dx.doi.org/10.1016/S0268-005X(01)00092-3

Mota, C. J. A., Silva, C. X. A., \& Gonçalves, V. L. C. (2009). Gliceroquímica: Novos produtos e processos a partir da glicerina de produção de biodiesel. Química nova, 32, 639-648. http://dx.doi.org/10.1590/S0100-40422009000300008

Oliveira, M. R., Silva, R. S. S. F., Buzato, J. B., \& Celligoi, M. A. P. C. (2007). Study of levan production by Zymomonas mobilis using regional low-cost carbohydrate sources. Biochemical engineering journal, 37, 177-183. http://dx.doi.org/10.1016/j.bej.2007.04.009

Prasanna, P. H. P., Bell, A., Grandison, A. S., \& Charalampopoulos, D. (2012). Emulsifying, rheological and physicochemical properties of exopolysaccharide produced by Bifidobacterium longum subsp. infantis CCUG 52486 and Bifidobacterium infantis NCIMB 702205. Carbohydrate polymers, $\quad 90, \quad 533-540$. http://dx.doi.org/10.1016/j.carbpol.2012.05.075

Prieto, L. M., Michelon, M., Burkert, J. F. M., Kalil, S. J., \& Burkert, C. A. V. (2008). The production of rhamnolipid by a Pseudomonas aeruginosa strain isolated from a southern coastal zone in Brazil. Chemosphere, 71, 1781-1785. http://dx.doi.org/10.1016/j.chemosphere.2008.01.003

Reis, E. C., Almeida, M., Cardoso, J. C., Pereira, M. A., Oliveira, C. B. Z., Venceslau, E. M., ... Padilha, F. F. (2010). Biopolymer synthesized by strains of Xanthomonas sp isolate from Brazil using biodiesel-waste. Macromolecular symposia, 296, 347-353. http://dx.doi.org/10.1002/masy.201051048

Rottava, I., Batesini, G., Silva, M. F., Lerin, L., Oliveira, D., Padilha, F. F., ... Treichel, H. (2009). Xanthan gum production and rheological behavior using different strains of $\begin{array}{lllll}\text { Xanthomonas } & \text { sp. } \quad \text { Carbohydrate } & \text { polymers, }\end{array}$ 
http://dx.doi.org/10.1016/j.carbpol.2008.12.001

Santos, E. O., Michelon, M., Gallas, J. A., Kalil, S. J., \& Burkert, C. A. V. (2013). Raw glycerol as substrate for the production of yeast biomass. International journal of food engineering, 9, 413-420. http://dx.doi.org/10.1515/ijfe-2012-0248

Silbir, S., Dagbagli, S., Yegin, S., Baysal, T., \& Goksungur, Y. (2014). Levan production by Zymomonas mobilis in batch and continuous fermentation systems. Carbøhydrate polymers, 99, 454-461. http://dx.doi.org/10.1016/j.carbpol.2013.08.031

Silva, G. P., Mack, M., \& Contiero, J. (2009a). Glycerol: A promising and abundant carbon source for industrial microbiology. Biotechnology advances, 27, 30-39. http://dx.doi.org/10.1016/j.biotechadv.2008.07.006

Silva, M. F., Fornari, R. C. G., Mazutti, M. A., Oliveira, D., Padilha, F. F., Cichoski, A. J., ... Treichel, H. (2009b). Production and characterization of xanthan gum by Xanthomonas campestris using cheese whey as sole carbon source. Journal of food engineering, 90, 119-123. http://dx.doi.org/10.1016/j.jfoodeng.2008.06.010

Spier, F., Buffon, J. G., \& Burkert, C. A. V. (2015). Bioconversion of raw glycerol generated from the synthesis of biodiesel by different oleaginous yeasts: Lipid content and fatty acid profile of biomass. Indian journal of microbiology. http://dx.doi.org/10.1007/s12088-015-0533-9

Staudt, A. K., Wolfe, L. G., \& Shrout, J. D. (2012). Variations in exopolysaccharide production by Rhizobium tropici. Archives of microbiology, 194, 197-206. http://dx.doi.org/10.1007/s00203-011-0742-5

West, T. P., \& Strohfus, B. (1998). Effect of carbon source on exopolysaccharide production by Sphingomonas paucimobilis ATCC 31461. Microbiological research, 153, 327-329. http://dx.doi.org/10.1016/S0944-5013(99)80045-7

Zhang, J., Dong, Y-C., Fan, L-L., Jiao, Z-H., \& Chen, Q-H. (2015). Optimization of culture medium compositions for gellan gum production by a halo bacterium Sphingomonas paucimobilis. Carbohydrate polymers, $\quad 115, \quad 694-700$. http://dx.doi.org/10.1016/j.carbpol.2014.09.029

Zhu, G., Sheng, L., \& Tong, Q. (2013). A new strategy to enhance gellan production by two-stage culture in Sphingomonas paucimobilis. Carbohydrate polymers, 98, 829-834. http://dx.doi.org/10.1016/j.carbpol.2013.06.060

\section{Copyright Disclaimer}

Copyright reserved by the author(s).

This article is an open-access article distributed under the terms and conditions of the Creative Commons Attribution license (http://creativecommons.org/licenses/by/3.0/). 